\title{
ТЕОРЕТИЧН АСПЕКТИ ФОРМУВАННЯ КОНЦЕПЦІЇ РАННЬОГО ВТРУЧАННЯ В ПСИХОЛОГО-ПЕДАГОГІЧНИХ ДОСЛІДЖЕННЯХ
}

Людмила Некраш, Центр раннього розвитку ВБО «Даун Синдром», м. Київ, Україна, nekrashlm@ukr.net

Узагальнено історичні аспекти формування концепції раннього втручання. Виявлено, що концепція раннього втручання формувалася на основі наукових досліджень, клінічного і практичного досвіду різних дисциплін (охорона здоров'я матері і дитини, дошкільна освіта, спеціальна педагогіка, психологія розвитку і нейробіологія), а також під впливом ініціатив і поширення руху батьків дітей з особливими потребами. Встановлено, що сучасна модель раннього втручання пропонує нові теоретичні уявлення і практичні підходи до розуміння проблем і потреб дітей раннього віку з порушеннями розвитку, у тому числі й немовлят, а також іх родин. Наразі актуальними є: перехід від форм втручання, спрямованих на дитину і усунення захворювання, до залучення батьків опікунів, членів родини, місцевої громади; долучення до цільової групи й дітей з ризиком виникнення порушень розвитку; перехід до функціональної класифрікації, зокрема, Міжнародної класифікації функціонування (МКФ).

Ключові слова: раннє втручання, особливі потреби, порушення розвитку

Людмила Некраш, Центр раннего развития ВБ0 «Даун Синдром», г. Киев, Украина Теоретические аспекты формирования концепции раннего вмешательства в психолого-педагогических исследованиях

Обобщены исторические аспекты формирования концепции раннего вмешательства. Выявлено, что модель раннего вмешательства формировалась на основе научных исследований и опыта различных дисциплин (охрана здоровья матери и ребенка, дошкольное образование, специальная педагогика, психология развития и нейробиология), а также под влиянием инициатив и распространение движения родителей детей с особыми потребностями. Установлено, что современная модель раннего вмешательства предлагает новые теоретические представления и практические подходы к пониманию проблем и потребностей детей раннего возраста с нарушениями развития, в том числе и младенцев, а также их семей. Сейчас актуальны: переход от фрорм вмешательства, направленных на ребенка и устранения заболевания, к привлечению родителей $\backslash$ опекунов, членов семьи, местной общины; приобщение к целевой группы и детей с риском возникновения нарушений развития; переход к фуннциональной классификации, в частности, Международной классификации функционирования (МКФ).

Ключевые слова: раннее вмешательство, особые потребности, нарушение развития

(C) Некраш Л., 2018 
Lyudmyla Nekrash, Early Development Syndrom ACO "Down Syndrom", Kyiv, Ukraine Theoretical aspects of the formation of the concept of early intervention in psychological and pedagogical research

Generalized historical aspects of the formation of the concept of early intervention. It was discovered that the model of early intervention was based on scientific research, clinical and practical experience of different disciplines (maternal and child health care, pre-school education, special pedagogy, developmental psychology and neurobiology), as well as under the influence of initiatives and propagation of the parents of children with special needs. It is established that a modern model of early intervention offers new theoretical concepts and practical approaches to understanding the problems and needs of young children with developmental disorders, including infants, and their families. The following are currently relevant: the transition from forms of intervention aimed at the child and the elimination of the disease, to the involvement of parents / guardians, family members, local community; admission to the target group and children at risk of developmental abnormalities; the transition to a functional classification, in particular, the International Classification of Functioning (ICF).

Keywords: early intervention, special needs, developmental disorders.

Постановка проблеми. Розвиток держави в контексті європейських орієнтирів передбачає зосередження уваги на дітях з особливими потребами через якнайраніше (з перших днів народження дитини) партнерство фахівців, сімі'ї та суспільства.

Водночас проблема раннього виявлення, профілактики порушень розвитку дитини та функціонування iї сім'ї, що забезпечується командою фахівців, наразі є новою для вітчизняної наукової спільноти.

Аналіз актуальних досліджень. Аналіз теоретичних джерел дав змогу виявити, що дослідники розглядають ранню комплексну допомогу дітям із порушеннями розвитку як систему - сукупність соціальної, медичної й спеціальної педагогічної підтримки. Ця система базується на культурно-історичній теорії Л. Виготського і його наукової школи, представники якої довели унікальність перших років життя дитини для ï розвитку (Л. Виготський, Л. Венгер, А. Запорожець, Д. Ельконін та інші). Науковцями доведено, що вік від народження до 3-х років є періодом стрімкого й інтенсивного формування якостей і властивостей особистості, які слугують фундаментом для придбання будь-яких компетенцій. Цей вік є сенситивним до зовнішніх чинників й відіграє особливу роль у розвитку дитини, створює сприятливі умови для виникнення психологічних новоутворень, що визначають формування іiї пізнавальної та особистісної сфери. Саме в перші роки життя дитини наявні унікальні можливості для втручання у розвиток, зокрема й з метою корекції порушень розвитку. Упущення сенситивного періоду надолужити надважко чи й неможливо (А. Катаєва, Е. Стребелева). У цьому контексті, у взаємозв'язку з проблемами сімейного виховання, розглядаються й питання виховання дітей раннього віку. Учені доводять, що саме родина найбільше впливає на становлення особистості дітей раннього та дошкільного віку (Л. Виготський, Л. Божович, А. Запорожець, І. Кон, А. Леонтьєв, М. Мухіна, О. Смирнова, Д. Ельконін та ін.)

«ОСОБЛИВА ДИТИНА: навчання і виховання», № 4, 2018 
Позиція українських науковців щодо ролі раннього виявлення, профілактики порушень розвитку дитини та функціонування ï сім'ї (Г. Кукуруза, К. Островська, Г. Соколова та інші) узгоджується із зарубіжними дослідженнями в царині раннього втручання («early intervention»), які були проведені в країнах близького зарубіжжя (М. Блюміна, Л. Журба, А. Катаєва, Е. Леонгард, Н. Малофєєв, Е. Мастюкова та інші), Свропи, США, Канади (M. Bruder, J. Cooper, R. Darling; M. Guralnick, R. McWilliam, S. Menuchin, J. Shonkoff, O. Speck та інші). Зважаючи на вищезазначене набуває поширення розвиток служб раннього втручання. Зростає чисельність і різноманітність програм з раннього втручання. Це дає змогу запропонувати широкий спектр послуг відповідно до різних потреб дітей 3 особливостями розвитку. Ефективність реалізації програм раннього втручання і їх вплив на дитину, iї родину та найближче оточення, а також суспільство обгрунтовано зарубіжними дослідженнями останніх двох десятиліть. Доведено, що втручання в ранньому дитинстві приносить негайну і тривалу користь для розвитку дитини та родини, й, водночас є фінансово грамотним рішенням зберігає кошти як в суспільстві, так і в сім'і $[1,2,8]$. 3-поміж наукових доказів $\epsilon$ й те, що програми раннього втручання приносять користь як дітям раннього віку, які мають ризик появи порушень, так і тим, у кого порушення вже встановлені [10]. Оскільки програми раннього втручання активно залучають оточення дитини (батьків, сім'ю, місцеву громаду та інших, пов'язаних з його розвитком системи), то й ефективність впливу раннього втручання підтверджується на різних рівнях, ілюструючи позитивний вплив на дитину, їі сім'ю і найближче оточення, й на суспільство загалом [7, 8, 15].

Також виникає необхідність у розробленні змісту і принципів раннього втручання, керуючись загальними принципами та особливостями, що є в основі розвитку теорії й практики раннього втручання в тій чи іншій країні. Ця проблема гостро постає і в України, що наразі долучається до провідних світових концептів раннього втручання.

Мета статті - узагальнити історичні аспекти формування концепції раннього втручання та наявні визначення, які описують модель раннього втручання; означити цільову групу, завдання та принципи раннього втручання.

У цій статті ми послуговуємося теоретичним аналізом та узагальненням даних наукової літератури з означеної проблеми дослідження, зокрема й стандартами Міжнародного Товариства Раннього Втручання, стандартами Свропейської Асоціації Раннього втручання, документами Європейського агентства 3 розвитку в галузі особливих освітніх потреб.

Виклад основного матеріалу. Досліджуючи поняття «раннє втручання» варто зазначити, що сучасне тлумачення раннього втручання характеризується розмаїттям інтерпретацій. Це пов'язують з культурними, політичними, економічними і суспільними процесами. Саме ці процеси окреслюють контекст формування і розвитку програм та послуг для дітей $з$ особливостями розвитку.

На сьогодні наявні різні трактування поняття раннє втручання. Так, за визначенням Європейської асоціації раннього втручання «Eurlyaid» (1993) ранне втручання «...являє собою всі види заходів, орієнтованих на розвиток дитини, а також на супровід батьків, які здійснюються безпосередньо й негайно після 
визначення стану та рівня розвитку дитини. Раннє втручання спрямоване як на дитину, так і на батьків, сім'ю та ії соціальне оточення».

Свропейське агентство з розвитку у сфері особливих освітніх потреб у 2005 році в своїй ухвалі про Раннє втручання відзначило що, раннє втручання має бути сукупністю послуг/ресурсів для дітей раннього віку та їх сімей. Ці послуги мають надаватися на їх запит і охоплювати будь-які заходи, які здійснюються тоді, коли дитина потребує особливої підтримки.

Подібні погляди знаходимо в Стандартних вимогах до організації діяльності служби Раннього втручання (2012), що розроблені й опубліковані Російською асоціацією раннього втручання спільно з Європейською асоціацією з раннього втручання. Так, раннє втручання трактується як система заходів, спрямованих на розвиток дітей раннього віку з порушеннями розвитку або ризиком появи таких порушень, і заходів, орієнтованих на підтримку батьків [13].

Основні аспекти раннього втручання висвітлені в працях М. Гуральніка. Дослідник зазначає, що раннє втручання - це «... система, створена для підтримки сімейних моделей взаємодії, які найкращим чином сприяють дитячому розвитку» [2; 3]. Наскрізно підкреслюється важливість взаємодії між батьками і дитиною, значущість щоденного досвіду, який дитина отримує у власній родині, а також надання допомоги батькам для забезпечення здоров'я і безпеки дитини. Подібну позицію висвітлено у працях J.W. Jacobson, J. A. Mulick, \& J. Rojahn та ін.

Наразі в Україні лише формується політика послуги раннього втручання. На практиці використовується таке визначення раннього втручання: «Ранне втручання - це спеціально організована система психологічної, соціальної, медичної і педагогічної допомоги сім'ям, які виховують дітей від народження до 4 років із порушеннями розвитку або ризиком їх виявлення, спрямованої на розвиток дитини і нормалізації життя іiі сім'ї» [5; 6].

Узагальнюючи, можна стверджувати, що, незважаючи на різноманітність вищезапропонованих визначень, усі вони підкреслюють важливість забезпечення широкого спектра послуг на ранніх етапах розвитку для дітей із порушеннями розвитку або ризиком появи таких порушень, а також залучення батьків, сім'ї, і безпосереднього оточення дитини до надання послуг раннього втручання.

Сприятливий суспільно-політичних клімат для розвитку програм і послуг для дітей з особливими потребами спостерігається від початку 1960-х років, й знаменується впровадженням відповідної законодавчої бази для надання допомоги дітям із порушенням розвитку або ризиком його виникнення у США й інших країнах Західної Європи.

Виникненню сучасної концепції раннього втручання передував громадський і батьківський рух «щодо захисту прав дітей з інвалідністю». Саме завдяки активному внеску Нідерландської організації батьків дітей із порушеннями розвитку «BOSK» у 1989 році виникла Європейська Асоціація Раннього втручання. За ії сприяння здійснено перехід до функціональної класифікації, а згодом до Міжнародної класифікації функціонування, обмежень життєдіяльності та здоров'я (МКФ), рекомендованої ВООЗ (2001), що наразі запроваджується й в Україні [7].

Досліджуючи історичні аспекти формування концепції раннього втручання варто зазначити, що виокремлюють низку завдань, які є універсальними для служб

«ОСОБЛИВА ДИТИНА: навчання і виховання», № 4, 2018 91 
раннього втручання. А саме: ранне виявлення порушень у розвитку немовляти і дитини раннього віку; забезпечення послуг з розвитку дітей раннього віку, які мають порушення, з метою уникнення затримки в розвитку або іiі мінімізація; формування і розвиток спроможності дітей раннього віку, що мають порушення або ризик ї виникнення, до самостійного життя в суспільстві; скорочення витрат на спеціальну освіту дітей і зменшення, таким чином, потреби в спеціальній освіті і догляді після досягнення ними шкільного віку; надання допомоги батькам у створенні оптимальних умов для розвитку і навчання дитини в умовах сім'ї і місцевої громади; підвищення рівня компетентності батьків та інших членів сім'ї, що приводить до розширення і зміцнення їх можливостей щодо задоволення особливих потреб своєї дитини; сприяння соціальній інтеграції сім'ї та дитини $[4 ; 13 ; 15 ; 16]$.

Відповідно основними завданнями раннього втручання визначено: інформаційна та емоційна підтримка сім'ям; мобілізація ресурсів сімей та забезпечення зв'язків з іншими ресурсами в їхньому найближчому оточенні і місцевому співтоваристві; комплексна оцінка рівня розвитку дитини; розроблення і реалізація спільно з сім'єю індивідуальної програми втручання; координація і взаємодія 3 іншими службами, що забезпечують послуги для дитини і сім'ї; організація груп підтримки для сімей (European Agency, 2005, Eurlyaid, 1993).

Водночас дослідники наголошують, що, окрім сприяння розвитку дитини і мінімізації потенційної загрози затримки в розвитку чи наявних проблем, одним з основних завдань раннього втручання має бути запобігання інституціоналізації (Meisels, S. J., Shonkoff, J. Р.). Це зреалізовується через низку терапевтичних послуг та розвиваючих програм для дітей та підтримку й навчання для їхніх батьків. Наразі питання є актуальним для країн Східної Європи і СНД, де й донині констатують найвищий у світі відсоток дітей, які проживають в інтернатних установах.

Аналізуючи наявні системи надання послуг раннього втручання, зокрема й за матеріалами нашого стажування в м. Люцерн, м. Вайдматт, м. Цуг (Швейцарія) можемо зазначити, що цільовою групою є діти та їхні родини. А саме діти, відповідної вікової категорії, мають порушення розвитку, чи високий ризик порушення в розвитку крупної чи дрібної моторики, сенсорного сприймання, когнітивній сфері, комунікації, адаптивній поведінці, соціальних навичок чи самообслуговування. Можна стверджувати, що у ранньому втручанні послуги надають на ранніх етапах розвитку дитини. Утім, як зазначено Європейською асоціацією раннього втручання «Eurlyaid», пренатальна діагностика далеко не всіма фахівцями розглядається як інтегральна частина раннього втручання, для батьків психосоціальні наслідки встановлення діагнозу в пренатальний період також дають підстави для звернення до служби раннього втручання.

Очевидно, що послуги раннього втручання мають надаватися з моменту народження дитини. Аналіз критеріїв залучення дітей раннього віку до програм раннього втручання в різних країнах дає змогу виокремити низку спільних критеріїв. А саме: порушення у розвитку (будь-яка із сфер на більше ніж два стандартних відхилення); порушення, що виявлене за допомогою норматованих шкал; наявність особливих потреб для розвитку, навчання та адаптації в суспільстві; народження від матерів, які вживають алкоголь 
або наркотичні речовини під час вагітності; деривація чи виявлення насилля над дитиною.

Досліджуючи поняття «раннє втручання» розуміємо вік виходу з програми раннього втручання як такий, що варіюється (від від 3-х до 6 років у різних програмах і країнах). Це залежить від наявності послуг і віку дитини на момент початку надання послуг. Так, зокрема, Європейська Асоціація Раннього втручання надає послуги дітям до вступу до школи. У Європейський країнах це зазвичай від 4 до 6 років. У США ці послуги надають до 3 років. Російська асоціація раннього втручання надає послуги дітям також до 3 років. За наявності ресурсів служби - вік дітей цільової групи може бути розширений до 6 років. Це актуально за відсутності умов для відвідування дошкільного освітнього закладу.

Не зважаючи на різноманітність програм раннього втручання, розроблено низку спільних вимог, що представлено службам раннього втручання згідно 3 документами Європейського агентства з розвитку у сфері особливих освітніх потреб [4]. Розкриємо їх

- загальна доступність передбачає, що послуги раннього втручання є доступними для кожної родини, яка занепокоєна станом дитини або ії розвитком);

- географічна доступність передбачає, що послуга раннього втручання має бути територіально доступною для родини і дитини;

- фінансова доступність передбачає безоплатну або мінімальну оплату за надання послуг;

- міждисциплінарна робота передбачає, що діяльність фахівців супроводжується постійним обміном інформацією, експертизою і будується на партнерській взаємодії;

- різноманітність програм і послуг, що передбачає зміну чи варіації програм відповідно до потреб дітей та їх родин.

Окрім вищеозначених вимог щодо програм раннього втручання, наявна низка першочергових принципів, на яких грунтується робота служб раннього втручання. Європейська Асоціація Раннього втручання пропонує послуговуватися такими базовими принципами роботи служб раннього втручання: послуги сімейно-центровані та орієнтовані на потреби кожної родини; послуги, що охоплюють усі сфери життя і розвитку дитини; послуги спрямовані на розвиток дитини в природному середовищі; науковість і доказовість використовуваних практик.

Отже, узагальнені історичні аспекти формування концепції раннього втручання та наявні визначення, які описують модель раннього втручання у пропонованому дослідженні, дають змогу розглядати нові теоретичні уявлення і практичні підходи до розуміння проблем і потреб дітей раннього віку з порушеннями розвитку, зокрема й немовлят, а також їх родин. Наразі актуальними для подальшого дослідження є перехід від форм втручання, спрямованих на дитину i усунення захворювання, до залучення батьків / опікунів, членів родини, місцевої громади; долучення до цільової групи й дітей з ризиком виникнення порушень розвитку; перехід до функціональної класифікації, зокрема, Міжнародної класифікації функціонування (МКФ). Актуальності дослідженню надають і специфічні завдання, пов'язані з культурним, політичним і економічним контекстом на українських теренах.

«ОСОБЛИВА ДИТИНА: навчання і виховання», № 4, 2018 93 


\section{ЛITEPATУPA}

1. Meisels S. J., Shonkoff J. P. (2000). Early childhood intervention: A continuing evolution. In J. P. Shonkoff, S. J. Meisels (Eds.), Handbook of early childhood intervention (second editon, pp. 3-31). Nev York: Cambridge universiny Press.

2. Guralnick M. J. (1998). The effectiveness of early intervention for vulnerable children: A developmental perspective. American Journal on Mental Retardation, 102, 319-345.

3. Guralnick M.J. (2011) Why early intervention works: A systems perspective. Infants and Young Children. 24, 6-28.

4. European Agency (2005). Early Childhood Intervention: Analysis of Situations in Europe Key Aspects and Recommendations. Available on the http://www.european-agency. org/ publications/ereports/early-childhood-intervention/early-childhood-intervention-analysis-ofsituations-in-europe-key-aspects-and-recommendations website (retrieved 22.08.2013)

5. Міжнародна класифікація функціонування, обмеження життедіяльності та здоров'я: діти та підлітки (версія): МКФ-ДП [Електронний ресурс]. - Режим доступу: http://moz.gov. ua/uploads/1/5263-dn_20180523_981_dod_2.pdf

6. Розпорядженням Кабінету Міністрів України від 27 грудня 2017 р. № 1008-р[Електронний ресурс]. - Режим доступу: http://zakon2.rada.gov.ua/laws/show/1008-2017-\%D1\%80

7. Доброва-Крол Н. Раннее вмешательство: Ключевые аспекты и международный опыт. Международный детский фонд ООН (ЮНИСЕФ) / Н. Доброва-Крол. - К., 2014. - 48 с.

8. Dunst, C.J. (2004). An integrated framework for practicing early childhood intervention and family support. Perspectives in Education, 22(2), 1-16.

9. EADSNE (2010), Early Childhood Intervention - Progress and Developments, 2005- 2010.

10. Ramey S., Ramey C., $\mathcal{E}$ Lanzi R. (2007). Early intervention: Background, research findings, and future directions. In J.W. Jacobson, J. A. Mulick, \& J. Rojahn (Eds.). Handbook of intellectual and developmental disabilities (pp. 445-463). NY: Springer.

11. Кукуруза Г. В. Ефективність програм раннього втручання для дітей з порушенням психічного розвитку / Г. В. Кукуруза // Вісник Харківського національного університету імені В. Н. Каразіна. Серія : Психологія. - 2013. - № 1046, вип. 51. - С. 184-186. - Режим доступу: http://nbuv.gov.ua/UJRN/VKhIPC_2013_1046_51_42.

12. King G., Strachan D., Tucker M. et all. The Application of a Transdisciplinary Model for Early Intervention Services//Infants \& Young Children. - July/September 2009 - Vol. 22 - Issue 3 - p. 211-223.

13. Аксенова О. Ж., Баранова Н. Ю., Емеи, М. М., Самарина Л. В. (2012) Стандартные требования к организации деятельности службы раннего вмешательства. Санкт-Петербург.

14. Early Childhood Outcomes Center (2011). Summary of 2011 child outcomes data. http:// www.fpg.unc.edu/ eco/assets/pdfs/outcomesforchildrenfinal.pdf

15. Eurlyaid (Eds.) (1997). Meeting of the working party Eurlyaid Cannaro, 9-12.10.1997. (unpublished working paper).

\section{REFERENCES (TRANSLATED AND TRANSLITERATED)}

1. Meisels S.J., Shonkoff J. P. (2000). Early childhood intervention: A continuing evolution. In J. P. Shonkoff, S. J. Meisels (Eds.), Handbook of early childhood intervention (second editon, pp. 3-31). Nev York: Cambridge universiny Press. 
2. Guralnick, M. J. (1998). The effectiveness of early intervention for vulnerable children: A developmental perspective. American Journal on Mental Retardation, 102, 319-345.

3. Guralnick, M. J. (2011) Why early intervention works: A systems perspective. Infants and Young Children. 24, 6-28.

4. European Agency (2005). Early Childhood Intervention: Analysis of Situations in Europe Key Aspects and Recommendations. Available on the http://www.european-agency. org/ publications/ereports/early-childhood-intervention/early-childhood-intervention-analysis-ofsituations-in-europe-key-aspects-and-recommendations website (retrieved 22.08.2013

5. Mizhnarodna klasyfikatsiia funktsionuvannia, obmezhennia zhyttiediialnosti ta zdorov'ia: dity ta pidlitky (versiia): MKF-DP [Elektronnyi resurs]. Electronic resource. Mode of access : http://moz.gov.ua/uploads/1/5263-dn_20180523_981_dod_2.pdf[In Ukrainian].

6. Rozporiadzhenniam Kabinetu Ministriv Ukrainy vid 27 hrudnia 2017 r. № 1008-r[Elektronnyi resurs]. Electronic resource. Mode of access : http://zakon2.rada.gov.ua/laws/show/1008-2017$\%$ D1\%80 [In Ukrainian].

7. Dobrova-Krol N. (2014). Rannee vmeshatelstvo: Kliuchevыe aspektы у mezhdunarodnыi орыt. Mezhdunarodnыi detskyi fond OON (IuNYSEF) / N. Dobrova-Krol.

8. Dunst, C.J. (2004). An integrated framework for practicing early childhood intervention and family support. Perspectives in Education, 22(2), 1-16.

9. EADSNE (2010), Early Childhood Intervention - Progress and Developments, 2005- 2010.

10. Ramey S., Ramey C., E Lanzi R. (2007). Early intervention: Background, research findings, and future directions. In J.W. Jacobson, J. A. Mulick, \& J. Rojahn (Eds.). Handbook of intellectual and developmental disabilities (pp. 445-463). NY: Springer.

11. Kukuruza $H$. V. Efektyvnist prohram rannoho vtruchannia dlia ditei z porushenniam psykhichnoho rozvytku / H. V. Kukuruza // Visnyk Kharkivskoho natsionalnoho universytetu imeni V. N. Karazina. Seriia : Psykholohiia. - 2013. - № 1046, vyp. 51. - S. 184-186. Electronic resource. Mode of access: http://nbuv.gov.ua/UJRN/VKhIPC_2013_1046_51_42. [In Ukrainian].

12. King G., Strachan D., Tucker M. et all. The Application of a Transdisciplinary Model for Early Intervention Services//Infants \& Young Children. - July/September 2009, Vol. 22 - Issue 3, pp. 211-223.

13. Aksenova O. Zh., Baranova N. Yu., Emets M. M., Samaryna L. V. (2012) Standartnыe trebovanyia k orhanyzatsyy deiatelnosty sluzhbы ranneho vmeshatelstva. Sankt-Peterburh.

14. Early Childhood Outcomes Center (2011). Summary of 2011 child outcomes data. http:// www.fpg.unc.edu/ eco/assets/pdfs/outcomesforchildrenfinal.pdf

15. Eurlyaid (Eds.) (1997). Meeting of the working party Eurlyaid Cannaro, 9-12.10.1997. (unpublished working paper). 